\title{
A Rare Case of Cold Agglutinin Hemolytic Anemia Induced Gangrene \\ LOVE DAOUD, ${ }^{1}$ VIVIAN SHOKRY, ${ }^{2}$ EHAB DAOUD ${ }^{3}$
}

\begin{abstract}
:
Gangrene is a rare and extreme presentation of cold agglutinin disease and our case is one of only few published reports in medical literature (less than twenty). In our patient severe hemolysis as manifested by elevated indirect bilirubin, LDH and low haptoglobin was triggered by unusual infectious organisms ( $E$. Coli and Coagulase negative Staphylococcus).
\end{abstract}

Key words: cold agglutinin, hemolytic anemia, gangrene.

\section{Introduction}

Cold agglutinin hemolytic anemia is a rare autoimmune hemolytic anemia secondary to antibodies that generally react with antigens on the RBC surface only at temperatures below that of the core temperature of the body. Acrocyanosis is a common finding, but gangrene is a rare presentation.

\section{Case report:}

Sixty nine year old caucasian male presented to the hospital with unresponsiveness, septic shock, hypothermia and acrocyanosis. He has a history of paranoia, cold agglutinins hemolytic anemia, and Raynaud disease for which he always wears gloves and stockings. In the ICU he had evidence of severe hemolysis with marked jaundice, elevated LDH and

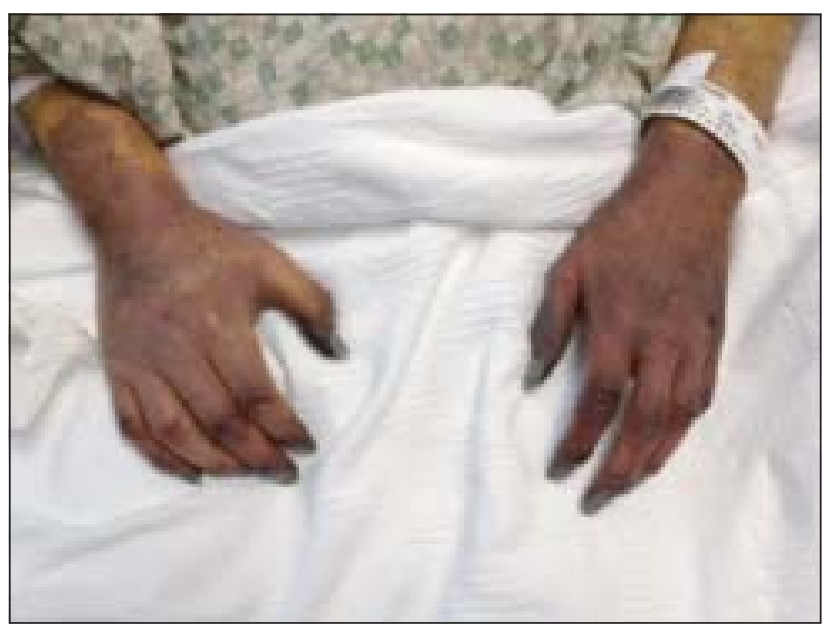

Fig.-1: Gangrene of both hands

1. Emergency department, Kent Hospital, USA

2. Department of Internal Medicine, Kent Hospital

3. Department of Intensive Care Medicine, Kent Hospital.

Correspondence: Dr. Ehab Daoud, MD, FACP, FCCP. Department of Intensive Care Medicine, Kent Hospital. Email: ehab_daoud@hotmail.com, Tel: 1 (440) 655-9697. low haptoglobin. His acrocyanosis had progressed to intense gangrene in "stock and glove" distribution. (Figures 1 \& 2) Treatment was started with passive warming, resuscitation, antibiotics, and steroids. Treatment with intravenous steroids was ineffective and cytotoxic agents were not used due to sepsis and multi system organ failure. The patient's condition continued to deteriorate with the multiple system organ failure and eventually succumbed to death.

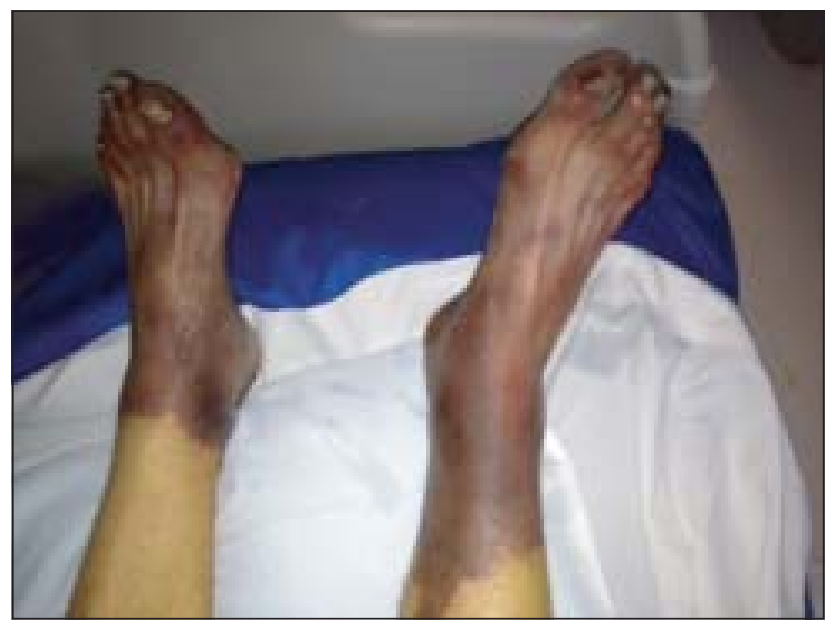

Fig.-2: Gangrene of both feet

\section{Discussion:}

Cold agglutinins hemolytic anemia is an autoimmune hemolytic anemia secondary to IgM antibodies that generally react with polysaccharide antigens on the RBC surface only at temperatures below that of the core temperature of the body. They are therefore called "cold agglutinins.” Rarely, IgG antibodies have these reaction characteristics, occurring either alone or with IgM antibodies. ${ }^{1}$ The antigens are the i antigen and the I antigen, coded by a gene on chromosome 14q. The haemolysis is due to complement fixation in the intravascular compartment, and the majority of the complement coated cells are destroyed extravascularly by the reticulo-endothelial system. ${ }^{2}$ 
Cold agglutinin disease was first reported in animals in 1903 by Landsteiner, and first human case reported in 1918 by Clough. ${ }^{3}$ It is a rare disease, most often affecting females in the seventh decade of life, with an incidence of one case per million people per year. ${ }^{4}$

Cold agglutinins are produced either in response to infection ${ }^{5}$ or by paraneoplastic or neoplastic growth. ${ }^{6}$ The most common infectious agents are: Mycoplasma pneumoniae, and infectious mononucleosis. Less commonly, cold agglutinins are associated with other bacterial and viral diseases, such as Cytomegalovirus, Epstein-Barr virus, Legionella, Citrobacter, Influenza, Varicella and Listeria Monocytogenes. ${ }^{4,6}$

Most common symptoms include anemia - 35 percent, acrocyanosis - 24 percent, fatigue - 21 percent, weakness or dyspnea on exertion -7 percent, hemoglobinuria - 3 percent. ${ }^{6}$ Diagnosis is made by presence of a high titer of cold agglutinins (excess of 1 in 10,000). Positive direct antiglobulin (Coombs) test for the presence of bound complement on red cells. The test is usually negative for bound IgG. The additional diagnosis of mycoplasma infection, infectious mononucleosis, or lymphoma should be made under appropriate clinical circumstances. ${ }^{7}$ Avoidance of cold is the most beneficial therapy to prevent hemolysis. Over the years, treatment has been directed at suppressing the synthesis of the IgM monoclonal protein and has included corticosteroids, alkylating agents, azathioprine, interferon, and purine nucleoside analogues. 6,7 Recently the monoclonal anti-CD20 antibody rituximab, alone or in combination with fludarabine has shown better results than corticosteroids and alkylating agents. ${ }^{8}$ Plasmapheresis can be used as adjunctive treatment to physically remove the IgM antibody from the plasma, leading to a reduction in the rate of hemolysis. ${ }^{9} 9$.

Table-I

Summarizes the published reports of cold agglutinin disease associated with gangrene.

\begin{tabular}{llc}
\hline Case/Reference & Description & Outcome \\
\hline Karunarathne et al. ${ }^{2} 2012$ & $\begin{array}{l}\text { Cold autoimmune haemolytic anaemia secondary to Epstein Barr virus } \\
\text { infection presenting with peripheral gangrene }\end{array}$ & $\begin{array}{c}\text { Amputation, } \\
\text { Survived }\end{array}$ \\
Bachmeyer C, et al. ${ }^{10} 2003$ & $\begin{array}{l}\text { Raynaud's phenomenon with necrosis of the extremities induced by } \\
\text { cold agglutinin disease secondary to a T-cell lymphoma }\end{array}$ & Died
\end{tabular}

Talisman et al. ${ }^{11} 1998$

Gangrene of the back, buttocks, fingers and toes caused by transient cold

Amputation, agglutinemia induced by a cooling blanket in a patient with sepsis

Survived

Patel M, et al. ${ }^{12} 1993$

Paroxysmal cold haemoglobinuria coexisting with cold agglutinins in a patient with syphilis resulting in peripheral gangrene

Freedman J, et al. ${ }^{13} 1985$

Autoimmune hemolytic anemia with concurrence of warm and cold red

Survived cell autoantibodies and a warm hemolysin.

Poldre P, et al. ${ }^{14} 1985$

Fulminant gangrene in transient cold agglutinemia associated with Escherichia coli infecion

Barth JH. ${ }^{15} 1981$

Infectious mononucleosis complicated by cold agglutinins, cold urticaria and leg ulceration.

Jerry W, et al. ${ }^{16} 1978$

Cryopathic gangrene with an IgM lambda cryoprecipitating cold agglutinin

Survived

Survived

Unknown

Cold agglutinin disease with Raynaud's Phenomenon

Amputations, survived

Mitchell ABS, et al. ${ }^{17} 1974$

Symmetrical Peripheral Gangrene in Acquired Hemolytic Anemia

Survived

Kumar S, et al. 181958

Digits gangrene with high titres of cold agglutinin

Unknown

Nelson MG, et al. ${ }^{19} 1953$

Amputations, survived

Stats D, et al. ${ }^{20} 1943$

Cold hemagglutination with symmetric gangrene of the tips

Amputations, of the extremities. survived 


\section{References:}

1. Silberstein LE, Berkman EM, Schreiber AD. Cold hemagglutinin disease associated with IgG cold-reactive antibody. Ann Intern Med. 1987;106:238-42.

2. Karunarathne S, Weerasinghe S, Govindapala D, Fernando H, Jayaratne B.. Cold autoimmune haemolytic anaemia secondary to Epstein Barr virus infection presenting with peripheral gangrene; case report. Thrombosis Journal. 2012; 10:4-6.

3. Dacie JV, Crookston JH, Christenson WN. Incomplete cold antibodies role of complement in sensitization to antiglobulin serum by potentially haemolytic antibodies. Br J Haematol. 1957;3:77-87.

4. Berentsen S, Ulvestad E, Langholm R, Beiske K, HjorthHansen H, Ghanima W, et al. Primary chronic cold agglutinin disease: a population based clinical study of 86 patients. Haematologica. 2006;91:460-6.

5. McNicholl FP. Clinical syndromes associated with cold agglutinins. Transfus Sci. 2000;22:125-33.

6. Swiecicki PL, Hegerova LT, Gertz MA. Cold agglutinin disease. Blood. 2013;122:1114-21.

7. Gertz MA. Cold Hemolytic Syndrome. Hematology. 2006;1:19-23.

8. Berentsen S, Tjonnfjord GE, Brudevold R, Gjertsen BT, Langholm R, Lokkevik E et al. Favourable response to therapy with the anti-CD20 monoclonal antibody rituximab in primary chronic cold agglutinin disease. Br J Haematol. 2001;115:79-83.

9. Siami FS, Siami GA. A last resort modality using cryofiltration apheresis for the treatment of cold hemagglutinin disease in a Veterans Administration hospital. Ther Apher Dial. 2004;8:398-403.

10. Bachmeyer C, Blum L, Chesneau AM, Richecoeur J, Testard F, Benchaa B, et al. Raynaud's phenomenon with necrosis of the extremities induced by cold agglutinin disease secondary to a T-cell lymphoma. Acta Derm Venereol. 2003; 83:374-5.

11. Talisman R, Lin JT, Soroff HS, Galanakis D. Gangrene of the back, buttocks, fingers, and toes caused by transient cold agglutinemia induced by a cooling blanket in a patient with sepsis. Surgery. 1998;123:592-5.

12. Patel M, Durao H, Govender Y. Paroxysmal cold haemoglobinuria coexisting with cold agglutinins in a patient with syphilis resulting in peripheral gangrene: a case report. East Afr Med J. 1993;70:526-7.

13. Freedman J, Lim FC, Musclow E, Fernandes B, Rother I. Autoimmune hemolytic anemia with concurrence of warm and cold red cell autoantibodies and a warm hemolysin. Transfusion. 1985;25:368-72.

14. Poldre P, Pruzanski,t W, Chiu HM, Dotten DA. Fulminant gangrene in transient cold agglutinemia associated with Escherichia coli infection. CAN MED ASSOC J. 1985; 132:261-3.

15. Barth JH. Infectious mononucleosis (glandular fever) complicated by cold agglutinins, cold urticaria and leg ulceration. Acta Derm Venereol. 1981;61:451-2.

16. Kuenn JW, Weber R, Teage PO, Keitt AS. Cryopathic gangrene with an igm lambda cryoprecipitating cold agglutinin. Cancer. 1978;42:1826-33.

17. Mitchell ABS, Pegrum GD, Gill AM. Cold agglutinin disease with Raynaud's phenomenon. Proc R Soc Med. 1974; 67:113-5.

18. Kumar S, Singh MM, Bhatia BB, Mangalik VS. Symmetrical peripheral gangrene in acquired hemolytic anemia. Acta Haematol. 1958;19:369-77.

19. Nelson MG, Marshall RJ. The syndrome of high-titre cold haemagglutination. Br Med J. 1953;2:314-7.

20. Stats D, Bullowa JGM. Cold hemagglutination with symmetric gangrene of the tips of the extremities. Arch Intern Med. 1943;72:506-17. 